\title{
MACIEJ BORSKI
}

Wyższa Szkoła Humanitas w Sosnowcu

\author{
ŚWIADCZENIA OPIEKUŃCZE DLA OPIEKUNÓW \\ DOROSŁYCH OSÓB Z NIEPEŁNOSPRAWNOŚCIAMI - \\ PRZYKŁAD NIEKONSEKWENTNEJ POLITYKI PAŃSTWA
}

\section{WPROWADZENIE}

W ostatnich trzech dekadach, czyli od momentu rozpoczęcia transformacji ustrojowej, widoczny jest w Polsce ewidentny wzrost zainteresowania państwa sferą zabezpieczenia praw jednostek. Wzrost ten przejawia się między innymi w budowie (praktycznie od podstaw) prawno-instytucjonalnego systemu wsparcia osób z niepełnosprawnościami i ich opiekunów. To właśnie w latach 90. XX w. doszło do fundamentalnych zmian w zakresie wsparcia osób z niepełnosprawnościami i ich opiekunów. Wiele kompetencji z zakresu wsparcia należących dotąd do organów administracji rządowej przejętych zostało przez samorząd terytorialny i lokalne organizacje pozarządowe. Organizacje te stopniowo stawały się alternatywą dla niewydolnego, państwowego systemu opieki społecznej. Działały bardzo dynamicznie, dużo skuteczniej rozwiązując różnorodne problemy związane ze wsparciem zarówno osób z niepełnosprawnościami, jak i ich opiekunów.

Oczywiście wzrost zainteresowania państwa nie sprawił, że wyłączone zostało tzw. wsparcie nieformalne udzielane przede wszystkim przez rodzinę. To właśnie ona jest w sposób naturalny predystynowana 
do sprawowania opieki nad osobami niesamodzielnymi. Nie może jednak zostać ze wszystkimi problemami sama. Konieczne staje się wsparcie jej ze strony państwa. Wydaje się, że współcześnie władze publiczne dostrzegają tę konieczność, jednak próbują zrealizować ten cel przy możliwie najmniejszym zaangażowaniu finansowym. Wyraźny wzrost zainteresowania widoczny jest jedynie w okresie przedwyborczym ${ }^{1}$. Dopóki niesamodzielna osoba z niepełnosprawnością nie trafi do instytucji stałego pobytu (w ramach służby zdrowia lub sektora socjalnego), pozostaje w ogromnej mierze pod opieką bliskich. To właśnie od najbliższej rodziny oczekuje się poświęcenia i pomocy dla swojego podopiecznego, nie uwzględnia się natomiast zagrożeń i ukrytych bądź oddalonych w czasie kosztów indywidualnych, społecznych i ekonomicznych, takich jak ryzyko wykluczenia materialnego czy zawodowego, ograniczenia kontaktów towarzyskich i społecznej izolacji, a także pogorszenia stanu zdrowia opiekuna związanego z koncentracją całej uwagi na podopiecznym. Państwo stara się oczywiście zaspokajać potrzeby osoby z niepełnosprawnością. Otrzymuje ona wsparcie udzielane przez różnorodne instytucje, ale jest to zwykle wsparcie edukacyjne, rewalidacyjne, rehabilitacyjne, zdrowotne, skierowane bezpośrednio do osoby z niepełnosprawnością. Tymczasem typowe wsparcie opiekuńcze nie podlega kompleksowemu zabezpieczeniu. Widać więc, że państwo koncentruje się na wspieraniu osoby z niepełnosprawnością, pomijając jednak potrzeby jej opiekuna, tak jakby wychodziło z założenia, że sprawowanie opieki przez opiekuna jest jego naturalnym obowiązkiem, który zdejmuje z państwa konieczność zabezpieczenia potrzeb opiekuńczych osoby z niepełnosprawnością. Tymczasem opieka ta jest dla opiekuna ciężką pracą, która powinna być w odpowiedni sposób wynagradzana przez państwo².

1 Por. m.in. https://biznes.radiozet.pl/News/500-plus-dla-niepelnosprawnych-2019.-Sasin-wyplaty-od-pazdziernika.-Dla-kogo-Wnioski; https://dziennikbaltycki. pl/500-plus-dla-niepelnosprawnych-2019-kto-dostanie-jakie-kryteria-od-kiedy-staly-dodatek-dla-doroslych-niepelnosprawnych-4072019/ar/c3-14144213 (dostęp 10 kwietnia 2020 r.).

2 Por. M. Borski, Publiczne formy wspierania opiekunów osób z niepełnosprawnościami, Sosnowiec 2018, s. 42-43. 


\section{ZAGADNIENIA TERMINOLOGICZNE}

Refleksji nad udzielaniem przez państwo wsparcia w postaci świadczeń opiekuńczych dla opiekunów dorosłych osób z niepełnosprawnościami nie można oczywiście dokonać bez sprecyzowania zakresu podmiotowego prowadzonych rozważań. Konieczne staje się zatem ustalenie, kim jest opiekun dorosłej osoby z niepełnosprawnością i jak będzie on definiowany na potrzeby tego opracowania.

W polskim prawie funkcjonują dwie podstawowe kategorie opiekunów:

- opiekunowie prawni - ustanawiani przez sąd dla osób ubezwłasnowolnionych całkowicie;

- opiekunowie faktyczni - to osoby, które na co dzień sprawują pieczę nad osobą z niepełnosprawnością - sam fakt podjęcia opieki powoduje zatem, że ktoś staje się opiekunem faktycznym. Opiekun prawny jest ustanawiany przez sąd opiekuńczy w trybie art. 552-560 ${ }^{1}$ k.p.c. ${ }^{3}$, jeśli istnieją ku temu powody. Przyczyną takiej konieczności może być niezdolność do dbania o interesy osobiste, majątkowe czy potrzeby życiowe. Wyznaczony opiekun jest przedstawicielem ustawowym danej osoby, co oznacza, że może dokonywać czynności prawnych w jej imieniu. W pierwszej kolejności, zgodnie z art. 176 k.r.o. ${ }^{4}$ sąd ustanawia opiekunem prawnym małżonka lub rodziców. Dopiero w dalszej kolejności dokonuje wyboru spośród innych krewnych lub osób bliskich, pozostającego pod opieką. W braku takich osób sąd opiekuńczy zwraca się o wskazanie osoby, której opieka mogłaby być powierzona, do właściwej jednostki organizacyjnej pomocy społecznej albo do organizacji społecznej, a jeżeli pozostający pod opieką przebywa w placówce opiekuńczej albo innej podobnej placówce, sąd może się zwrócić także do tej placówki. Opiekunem nie może być osoba niemająca pełnej zdolności do czynności prawnych bądź osoba pozbawiona praw publicznych lub władzy rodzicielskiej. Ponadto nie może być to osoba

3 Ustawa z 17 listopada 1964 r. - Kodeks postępowania cywilnego (tekst jedn. Dz. U. z 2019 r., poz. 1460 ze zm.).

4 Ustawa z 25 lutego 1964 r. - Kodeks rodzinny i opiekuńczy (tekst jedn. Dz. U. z 2019 r., poz. 2086 ze zm.). 
skazana za przestępstwa przeciw wolności seksualnej lub obyczajności albo za umyślne przestępstwo z użyciem przemocy wobec osoby lub popełnione na jej szkodę lub we współdziałaniu z nią albo osoba, wobec której orzeczono zakaz prowadzenia działalności związanej z leczeniem czy opieką lub obowiązek powstrzymywania się od przebywania w określonych środowiskach lub miejscach, zakaz kontaktowania się z określonymi osobami lub zakaz opuszczania określonego miejsca pobytu bez zgody sądu. Warto również podkreślić, że nie może być ustanowiony opiekunem ten, w stosunku do kogo zachodzi prawdopodobieństwo, że nie wywiąże się należycie z obowiązków opiekuna.

Opiekun prawny ustanowiony dla osoby całkowicie ubezwłasnowolnionej obowiązany jest wykonywać swe czynności z należytą starannością, jak tego wymaga dobro pozostającego pod opieką i interes społeczny ${ }^{5}$. Opiekun powinien uzyskiwać zezwolenie sądu opiekuńczego we wszelkich ważniejszych sprawach, które dotyczą osoby ubezwłasnowolnionej całkowicie lub jej majątku. Zgodnie z art. $160 \$ 1$ k.r.o. niezwłocznie po objęciu opieki opiekun obowiązany jest sporządzić inwentarz majątku osoby pozostającej pod opieką i przedstawić go sądowi opiekuńczemu. Wymóg ten stosuje się odpowiednio także w razie późniejszego nabycia majątku przez osobę starszą. Sąd opiekuńczy może zwolnić opiekuna od obowiązku sporządzenia inwentarza, jeżeli majątek jest nieznaczny. Opiekun obowiązany jest, w terminach oznaczonych przez sąd opiekuńczy, nie rzadziej niż co roku, składać temu sądowi sprawozdania dotyczące osoby pozostającej pod opieką oraz rachunki z zarządu jego majątkiem. W razie zwolnienia opiekuna lub ustania opieki opiekun obowiązany jest złożyć w ciągu trzech miesięcy rachunek końcowy z zarządu majątkiem. Sąd może także zwolnić z obowiązku składania rachunku końcowego.

W świetle „Wytycznych w zakresie realizacji przedsięwzięć w obszarze włączenia społecznego i zwalczania ubóstwa z wykorzystaniem środków Europejskiego Funduszu Społecznego i Europejskiego Funduszu Rozwoju Regionalnego na lata 2014-2020” opiekun faktyczny to „osoba pełnoletnia opiekująca się osobą niesamodzielną, niebędąca opiekunem

5 Por. art. 154 k.r.o. 
zawodowym i niepobierająca wynagrodzenia z tytułu opieki nad osobą niesamodzielną, najczęściej członek rodziny"6. Także w literaturze można odnaleźć definicję opiekuna faktycznego. Według Magdaleny Rosochackiej-Gmitrzak opiekun faktyczny to osoba, która dostarcza regularnego, trwałego, fizycznego i (lub) emocjonalnego wsparcia oraz asysty przy czynnościach dnia codziennego komuś, kto jest fizycznie lub intelektualnie niepełnosprawny, psychicznie chory albo jest osobą starszą, której psychofizyczną kondycję można określić jako słabą7. Pojęcie opiekuna faktycznego jest zatem szersze niż pojęcie opiekuna prawnego. Do podstawowych form opieki sprawowanej przez opiekunów faktycznych należą: wsparcie emocjonalne, instrumentalne czynności wykonywane w domu i poza nim (np. transport, przygotowanie posiłków, zakupy), pielęgnacja i higiena osobista (np. kąpanie, karmienie, ubieranie, zmienianie pampersów) oraz nawiązywanie kontaktu $\mathrm{z}$ agendami specjalizującymi się w usługach dla seniorów, ich koordynacja i nadzór nad nimi ${ }^{8}$. Warto podkreślić, że sprawowana przez opiekunów faktycznych opieka ma charakter nieformalny i opiera się na idei wsparcia społecznego, odwołując się do zasobów rodziny, przyjaciół, sąsiadów. Opiekun nieformalny może współzamieszkiwać z osobą wymagającą opieki lub jedynie odpowiadać za zaspokojenie jej potrzeb, do których opiekun dostosowuje indywidualny tryb życia codziennego?

6 Wytyczne w zakresie realizacji przedsięwzięć w obszarze włączenia społecznego i zwalczania ubóstwa z wykorzystaniem środków Europejskiego Funduszu Społecznego i Europejskiego Funduszu Rozwoju Regionalnego na lata 2014-2020, - https://www. funduszeeuropejskie.gov.pl/media/49753/Wytyczne_wlaczenie_spoleczne_v4.pdf (dostęp 10 kwietnia 2020 r.).

M. RosochaскA-GMitrzaK, Wsparcie opiekunów nieformalnych - w strone równowagi społecznych oczekiwań i opiekuńczych możliwości rodzin, [w:] Publiczna troska, prywatna opieka. Społeczności lokalne wobec osób starszych, red. M. RACŁAW, Warszawa 2011, s. 140.

8 N.R. Hooyman, H.A. KIYAK, Social gerontology. A multidisciplinary perspective, Pearson Education, Inc., Boston 2011, s. 394.

9 M. CiszKowska-Giedziun, Instytucjonalne formy wsparcia osób starszych w Anglii, [w:] Działanie społeczne w pracy socjalnej na progu XXI wieku, red. E. KARTowicz, A. Olubiński, Toruń 2003, s. 502. 
Pojęcie opiekuna faktycznego funkcjonuje także na gruncie prawa medycznego. Przepis art. 3 ust. 1 ustawy o prawach pacjenta i Rzeczniku Praw Pacjenta ${ }^{10}$ w pkt 1 definiuje opiekuna faktycznego jako osobę sprawującą bez obowiązku ustawowego stałą opiekę nad pacjentem, który ze względu na wiek, stan zdrowia albo stan psychiczny opieki takiej wymaga. W literaturze podkreśla się, że nie każda osoba bliska może być uznana za opiekuna faktycznego. Nie wystarczy tu związek krwi czy też istnienie związku emocjonalnego, koniecznym elementem jest stała piecza nad pacjentem ${ }^{11}$. O stałej pieczy można mówić wówczas, gdy dana osoba sprawuje ją przez cały czas występowania okoliczności ją usprawiedliwiającej. Dla przyjęcia stałości pieczy nie ma znaczenia jej długotrwałość. W praktyce zatem opiekunem faktycznym pacjenta może być sąsiadka, opiekun, który bez obowiązku ustawowego sprawuje tego typu pieczę nad pacjentem (np. opiekun w domu pomocy społecznej). Faktyczna piecza tym zatem różni się od prawnej, że nie wyznaczają jej przepisy ustawowe (tak jak się to dzieje w odniesieniu do osób, wobec których istnieje prawny obowiązek pieczy ${ }^{12}$ ), lecz okoliczności wynikające z danego stanu faktycznego. Paradoksalnie, pojawiają się wątpliwości, czy jako opiekuna faktycznego można uznać współmałżonka, czy dorosłe dzieci osoby z niepełnosprawnością. Zdaniem Anny Dudzińskiej literalna wykładnia cytowanego art. 3 ust. 1 pkt 1 ustawy o prawach pacjenta nie pozwala uznać za opiekuna faktycznego małżonka czy dzieci pacjenta ze względu na wykonywanie przez te osoby pieczy na mocy obowiązku ustawowego ${ }^{13}$. Zgodnie bowiem z art. 23 k.r.o. małżonkowie są zobowiązani do wzajemnej pomocy, podobnie art. 87 k.r.o. stanowi, że rodzice i dzieci mają obowiązek wspierać się wzajemnie. Jak

10 Ustawa z 6 listopada 2008 r. o prawach pacjenta i Rzeczniku Praw Pacjenta (tekst jedn. Dz. U. z 2019 r., poz. 1127).

${ }_{11}$ Tak M. Świderska, Zgoda pacjenta na zabieg medyczny, Toruń 2007, s. 57; T. Dukiet-Nagórska, Świadoma zgoda pacjenta w ustawodawstwie polskim, «Prawo i Medycyna» 6-7/2000, s. 84; P. KonIECZniaK, Status prawny opiekuna faktycznego w prawie medycznym, «Prawo i Medycyna» 2/2014, s. 69-70.

12 Piecza jest sprawowana przez przedstawicieli ustawowych lub opiekunów prawnych.

13 A. DudziŃsKa, Wymagana informacja udzielana pacjentowi, «PiP» 63.9/2008, s. $99 \mathrm{i} \mathrm{n.}$ 
słusznie zauważa Urszula Drozdowska, definicja opiekuna faktycznego na gruncie prawa medycznego ma na celu objęcie możliwie najszerszego kręgu podmiotów, a zatem również tych osób, które bez obowiązku ustawowego sprawują stałą pieczę nad pacjentem ${ }^{14}$.

\section{STAN PRAWNy PRZED WYROKIEM TRYbUnaEU}

KONSTYTUCYJNEGO Z GRUDNIA 2013 R.

Sytuacja opiekunów dorosłych osób z niepełnosprawnościami zmieniała się na przestrzeni lat dość dynamicznie. W latach 2003-2009 świadczenia były kierowane wyłącznie do rodziców niepełnosprawnych dzieci i to pod warunkiem niskiego dochodu ${ }^{15}$. Wyrok Trybunału Konstytucyjnego z lipca 2008 r. ${ }^{16}$ przyczynił się do poszerzenia zakresu podmiotowego uprawnionych także o opiekunów osób dorosłych. Dało to podstawę do nowelizacji ustawy o świadczeniach rodzinnych, w wyniku której opiekunom dorosłych osób z niepełnosprawnościami również przyznano prawo do świadczenia pielęgnacyjnego ${ }^{17}$. Początkowo świadczenie to było przyznawane opiekunom spełniającym kryterium dochodowe, jednak pod koniec 2009 r. wraz z ustawą okołobudżetową ${ }^{18}$ zostało ono, prawdopodobnie $\mathrm{w}$ reakcji na protesty społeczne, zniesione. Przyznanie świadczeń pielęgnacyjnych opiekunom dorosłych osób z niepełnosprawnościami oraz likwidacja kryterium dochodowego doprowadziły do znacznego wzrostu ilości wypłacanych świadczeń pielęgnacyjnych, a w konsekwencji do wzrostu nakładów finansowych, jakie były na nie przeznaczane. Właśnie dlatego w grudniu

14 Por. U. Drozdowska, Status prawny partnera pacjenta w świetle uregulowań polskiego prawa medycznego, «Miscellanea Historico-Iuridica» 13.2/2014, s. 268.

15 Szerzej na ten temat por. R. BAKAlA RCzYK, Polityka wsparcia rodzin zosobami niepetnosprawnymi. W cieniu wyroków Trybunału Konstytucyjnego RP i protestów społecznych, «Studia z Polityki Publicznej» 1/2015, s. 63-80.

16 Wyrok TK z 18 lipca 2008 r., P 27/07, «OTK ZU» 6A/2008, poz. 107.

17 Ustawa z 17 października 2008 r. o zmianie ustawy o świadczeniach rodzinnych (Dz. U. Nr 223, poz. 1456).

18 Ustawa z 19 listopada 2009 r. o zmianie niektórych ustaw związanych z realizacją wydatków budżetowych (Dz. U. Nr 219, poz. 1706). 
2012 r. dokonano nowelizacji ustawy o świadczeniach rodzinnych, której celem było zahamowanie wzrostu kwot przeznaczanych na świadczenia pielęgnacyjne. Dokonano tego poprzez podział opiekunów osób z niepełnosprawnościami na dwie kategorie. Opiekunowie osób, które stały się niepełnosprawne w dzieciństwie, zachowali prawo do świadczenia pielęgnacyjnego na dotychczasowych zasadach. Z kolei opiekunowie osób, których niepełnosprawność powstała już w dorosłym życiu, mogli starać się jedynie o specjalny zasiłek opiekuńczy, obwarowany kryterium dochodowym, początkowo na poziomie 623 zł na osobę. Co ważne, by otrzymać świadczenie, nie wystarczyło pozostawanie poza zatrudnieniem; opiekunowie musieli wykazać, że rezygnacja $\mathrm{z}$ zatrudnienia nastąpiła w związku z koniecznością sprawowania opieki ${ }^{19}$. Tak rygorystycznie określone warunki spowodowały, że znaczna część opiekunów dorosłych osób z niepełnosprawnościami pozostała bez wsparcia bądź je utraciła. To właśnie wtedy pojawiła się społeczna kategoria tzw. wykluczonych opiekunów niepełnosprawnych osób dorosłych, którzy nie tylko przez społeczne protesty, lecz także na drodze prawnej zaczęli walczyć o utracone prawa. Warto w tym miejscu podkreślić za Rafałem Bakalarczykiem, że ważną, choć nie zawsze przywoływaną konsekwencją wspomnianej nowelizacji było pozbawienie tzw. wykluczonych opiekunów tytułu do ubezpieczeń emerytalno-rentowych i zdrowotnego w związku z utratą prawa do świadczeń, od których były odprowadzane składki. Tym samym zabezpieczenie społeczne dużej części opiekunów zostało znacznie ograniczone i to nie tylko w zakresie bieżących środków do życia w okresie sprawowania opieki, lecz także $\mathrm{w}$ wymiarze emerytalno-rentowym i zdrowotnym ${ }^{20}$.

19 Por. art. 16a ust. 1 ustawy z 28 listopada 2003 r. o świadczeniach rodzinnych (tekst jedn. Dz. U. z 2020 r., poz. 111) w wersji obowiązującej do 1 stycznia 2015 r.

20 R. BAKALARCZYK, Wybrane problemy zabezpieczenia społecznego osób opiekujacych się niesamodzielnymi bliskimi - wyzwania dla Sejmu VIII kadencji, «Ubezpieczenia Społeczne. Teoria i Praktyka» 3/2016, s. 50. 


\section{Wyroki TrybunaŁU Konstytucyjnego i ich WPŁyW na UKSZTAŁTOWANIE SIĘ UPRAWNIEŃ OPIEKUNÓW DOROSŁYCH OSÓB Z NIEPEŁNOSPRAWNOŚCIAMI}

Na palący problem tzw. wykluczonych opiekunów zwróciła uwagę ówczesna Rzecznik Praw Obywatelskich Irena Lipowicz, która skierowała stosowny wniosek do Trybunału Konstytucyjnego. Co ciekawe, podstawą wniosku nie było zróżnicowane traktowanie różnych kategorii opiekunów, lecz przepisy przejściowe dotyczące ustania prawa do świadczenia pielęgnacyjnego dla osób wcześniej je pobierających. Trybunał Konstytucyjny podzielił argumentację RPO i orzekł, że została złamana zasada ochrony praw nabytych i zasada zaufania do państwa oraz stanowionego przez nie prawa. Trybunał Konstytucyjny zwrócił uwagę, że „należy negatywnie ocenić labilność legislacji dotyczącej przesłanek świadczenia pielęgnacyjnego. Ponieważ w demokratycznym państwie prawnym chroni się zaufanie obywatela do państwa i stanowionego przez nie prawa, ustawodawca, dokonując kolejnych zmian stanu prawnego, nie może tracić z pola widzenia interesów podmiotów, jakie ukształtowały się przed dokonaniem zmiany stanu prawnego, co znaczy, że pożądaną cechą systemu prawa jest stabilność rozwiązań, zwłaszcza wobec osób o ograniczonych możliwościach adaptacyjnych”. Tymczasem zdaniem TK „zaskarżone przepisy nie zabezpieczyły w należyty sposób interesów osób, które w związku z pielęgnacją osoby niepełnosprawnej otrzymywały świadczenie pielęgnacyjne, i tym samym naruszyły ich bezpieczeństwo prawne (a w sposób pośredni również bezpieczeństwo osób niepełnosprawnych, przez odebranie wsparcia osobom opiekującym się nimi). Trybunał Konstytucyjny podzielił pogląd RPO, że „»Pułapka prawna« polega w tej sprawie na tym, że obywatel, opierając się na ustanowionych przez ustawodawcę przesłankach uzyskania świadczenia pielęgnacyjnego i działając w zaufaniu do stabilności przepisów prawa, dokonał istotnych wyborów życiowych, nie podejmując pracy zarobkowej lub rezygnując z zatrudnienia, a następnie - w rezultacie wygaśnięcia z mocy prawa decyzji uprawniającej do świadczenia pielęgnacyjnego i jednocześnie niespełniania nowych warunków przyznawania świadczenia pielęgnacyjnego, czy choćby specjalnego 
zasiłku opiekuńczego - utracił prawo do pobierania świadczenia i nie jest w stanie, ze względu na wcześniejszą rezygnację i trudną sytuację na rynku pracy, uzyskać ponownie zatrudnienia"21.

W konsekwencji powyższego wyroku ustawodawca podjął próbę stworzenia rozwiązań prawnych, które byłyby zgodne z wyżej wymienionymi zasadami konstytucyjnymi. Nastąpiło to po kilku miesiącach, gdy w życie weszła ustawa o ustaleniu i wypłacie zasiłków dla opiekunów ${ }^{22}$, która przewidywała nową formę wsparcia - zasiłek dla opiekuna. Zasiłek ten miał przysługiwać osobom, które są opiekunami osób dorosłych, jeśli niegdysiejsze prawo do świadczenia pielęgnacyjnego wygasło im z końcem czerwca 2013 r. (a więc z końcem okresu przejściowego obowiązywania nowelizacji ustawy o świadczeniach rodzinnych z grudnia 2012 r.). Warto w tym miejscu zauważyć, że wysokość zasiłku ustalono na poziomie $520 \mathrm{zł}$ i nie przewidziano jakiegokolwiek mechanizmu waloryzacji bądź weryfikacji wysokości świadczenia, choć osoby uprawnione otrzymały wyrównanie za okres, w którym pozostawały bez wsparcia, wraz z odsetkami.

Przyjęte przez ustawodawcę rozwiązania oznaczały nie tylko arbitralną nierówność statusu poszczególnych grup opiekunów osób z niepełnosprawnościami, lecz także znaczne ryzyko wykluczenia społecznego. O tym, że kwestia ta może przynieść znaczny kapitał polityczny, zaczęto zastanawiać się w opozycyjnym wówczas Prawie i Sprawiedliwości. To właśnie grupa posłów tego ugrupowania zaskarżyła wiele przepisów ustawy o świadczeniach rodzinnych do Trybunału Konstytucyjnego. Ich zastrzeżenia dotyczyły z jednej strony nierównego traktowania opiekunów ze względu na wiek, w którym powstała niepełnosprawność ich podopiecznych, z drugiej zaś stosowania kryterium dochodowego ograniczającego dostęp do świadczeń dla opiekunów dorosłych osób z niepełnosprawnościami. W wyroku z 21 października 2014 r. TK podkreślił, że różnicowanie opiekunów w podobnej sytuacji godzi w konstytucyjną zasadę równości. Podobnie jak w przypadku wcześniejszego

${ }^{21}$ Wyrok TK z 5 grudnia 2013 r., K 27/13, «OTK ZU» 9A/2013, poz. 134.

22 Ustawa z 4 kwietnia 2014 r. o ustaleniu i wypłacie zasiłków dla opiekunów (tekst jedn. Dz. U. z 2017 r., poz. 2092). 
wyroku TK z grudnia 2013 r. i tym razem ustawodawca został zobowiązany do podjęcia działań „bez zbędnej zwłoki”. Trybunał Konstytucyjny nie określił oczywiście wprost sposobu naprawy niekonstytucyjnego stanu prawnego, stwierdzając, że ustawodawca ma pewien margines swobody w zakresie ustalania, jaki model świadczeń dla opiekunów należy przyjąć. Zauważył jednak, że ustawodawca „powinien wszakże uwzględnić zarówno możliwości finansowania świadczeń z budżetu państwa, jak i uszanować poprawnie nabyte prawa osób, które korzystają obecnie ze świadczeń w zaufaniu do państwa”. Warto podkreślić, że TK nie podważył założenia, że „okres życia, w którym pojawia się niepełnosprawność, może mieć związek z oceną posiadania przez daną osobę majątku pozwalającego na samodzielne zapewnienie sobie godziwej egzystencji, jednak dotychczasowy sposób zastosowania przez ustawodawcę tego kryterium prowadził do arbitralnego zróżnicowania w obrębie tej samej grupy podmiotów podobnych". Trybunał wskazał, że „ustawodawca zobowiązany jest precyzyjnie określić racjonalne przesłanki, od których uzależni zróżnicowany poziom świadczenia dla opiekunów dorosłych osób niepełnosprawnych. Za punkt wyjścia musi jednak przyjąć jednakowe traktowanie takich opiekunów niezależnie od istniejącego już w ustawie preferencyjnego traktowania opiekunów niepełnosprawnych dzieci"23.

Aby zrealizować wyrok TK, Minister Pracy i Polityki Społecznej przygotował projekt nowelizacji, a następnie poddał go konsultacjom społecznym ${ }^{24}$. Projekt ten zakładał wprowadzenie jednego świadczenia pielęgnacyjnego dla wszystkich pozostających poza sferą zatrudnienia opiekunów zajmujących się bliskimi, bez względu na wiek, w którym powstała niesamodzielność, wprowadzając jednocześnie kryterium dochodowe warunkujące przyznanie świadczenia pielęgnacyjnego na poziomie 1000 zł netto na osobę. Projekt zakładał prawa nabyte dla osób korzystających z istniejącego systemu wsparcia wraz z możliwością wyboru przejścia na nowy system. Różnicował on także wysokość świadczenia

\footnotetext{
23 Wyrok TK z 21 października 2014 r., K 38/13, «OTK ZU» 9A/2014, poz. 104.

24 Por. https://legislacja.rcl.gov.pl/projekt/12270350/katalog/12280135\#12280135 (dostęp 10 kwietnia 2020 r.).
} 
pielęgnacyjnego według kryterium pełnoletności podopiecznego, a nie pełnoletności w momencie powstania niepełnosprawności. Propozycja zakładała przyznanie opiekunom osób niepełnoletnich kwoty 1200 zł, a pełnoletnich $-800 \mathrm{zł}^{25}$.

Projekt ustawy nie spotkał się z życzliwym przyjęciem środowiska opiekunów. Ponadto mocno podzielił on to środowisko. Rodzice dzieci z niepełnosprawnościami kontestowali propozycję przywrócenia kryterium dochodowego, które od 2010 r. ich nie obowiązywało. Wskazywali ponadto, że będzie to prowadziło do wykluczenia części opiekunów z systemu świadczeń, a także przełoży się na ryzyko ich ubóstwa w przyszłości, ponieważ za część z nich nie będą odprowadzane składki (problem, który już teraz dotyka część opiekunów osób dorosłych). Wskazywano też, że kryterium dochodowe może dezaktywizować innych członków rodziny, ponieważ obawa przed jego przekroczeniem w gospodarstwie domowym może zniechęcać do podejmowania pracy lub zwiększania jej wymiaru ${ }^{26}$. Zupełnie inaczej do tych propozycji odnieśli się opiekunowie dorosłych osób z niepełnosprawnościami, których zdaniem zawarte $\mathrm{w}$ ministerialnym projekcie rozwiązania nie objęłyby wszystkich potrzebujących, a także utrwaliłyby i jeszcze bardziej skomplikowały podziały w obrębie szerszej kategorii opiekunów osób z niepełnosprawnościami. Część z opiekunów była jednak skłonna zaakceptować takie rozwiązanie, twierdząc, że chociaż nie jest ono idealne, to mimo wszystko poprawia bardzo trudną sytuację opiekunów dorosłych osób z niepełnosprawnościami.

Ostatecznie, choć projekt został przyjęty przez Komitet Stały Rady Ministrów, to jednak nie został on poddany procesowi legislacyjnemu. Wydaje się, że brak stosownej inicjatywy ustawodawczej związany był także z nadchodzącą zmianą polityczną. Konsultacje prowadzone były na wiosnę 2015 r., a więc w okresie wyborczej kampanii prezydenckiej, która poprzedzała z kolei kampanię wyborczą do parlamentu. W związku z tym, że zakładano już rychłą zmianę władzy, zabrakło

25 Por. uzasadnienie do projektu ustawy o zmianie ustawy o świadczeniach rodzinnych oraz niektórych innych ustaw z 16 marca 2015 r., https://legislacja.rcl.gov.pl/ docs//2/12270350/12280135/12280136/dokument186241.pdf (dostęp 10 kwietnia 2020 r.).

26 Szerzej R. BAKALARCZyK, Wybrane problemy..., s. 55. 
zatem determinacji, aby rozwiązania, co do których nie było w środowisku opiekunów osób z niepełnosprawnościami jednomyślności, wprowadzić w życie.

4 listopada 2016 r. wpłynął do Sejmu poselski projekt ustawy o zmianie ustawy o świadczeniach rodzinnych oraz niektórych innych ustaw ${ }^{27}$. Projekt ten został złożony przez grupę posłów Nowoczesnej. Projekt przewidywał przyznanie świadczenia pielęgnacyjnego w równej wysokości dla wszystkich osób sprawujących faktyczną opiekę nad osobami $\mathrm{z}$ niepełnosprawnościami, jeśli nie podejmują lub rezygnują one $\mathrm{z}$ zatrudnienia lub innej pracy etatowej w celu sprawowania opieki. Projekt 2 grudnia 2016 r. został skierowany do pierwszego czytania w Komisji Polityki Społecznej i Rodziny, które odbyło się dopiero 6 lutego 2018 r. Na posiedzeniu projekt został skierowany do dalszych prac w podkomisji stałej do spraw osób niepełnosprawnych. Do zakończenia VIII kadencji Sejmu żadne dalsze prace w tym zakresie nie zostały podjęte. Po jej zakończeniu natomiast zgodnie z zasadą dyskontynuacji prac parlamentu prace w tym zakresie zostały zamknięte.

Oficjalnie rząd prezentuje stanowisko, że pełne wykonanie wyroku TK z 21 października 2014 r. będzie możliwe dopiero po zakończeniu prac nad reformą systemu orzecznictwa i stworzeniu kompleksowego systemu wsparcia osób z niepełnosprawnościami. Kiedy to jednak nastąpi, nie wiadomo.

5. RODZAJE ŚWIADCZEŃ OPIEKUŃCZYCH DLA OPIEKUNÓW DOROSŁYCH OSÓB Z NIEPEŁNOSPRAWNOŚCIAMI - STAN DE LEGE LATA

Z dotychczasowych rozważań widać, że ustawodawcy brakowało i wciąż brakuje spójnej wizji zabezpieczenia potrzeb opiekunów osób z niepełnosprawnościami. W sytuacji, gdy zwiększone środki przyznano

27 Por. Poselski projekt ustawy o zmianie ustawy o świadczeniach rodzinnych oraz niektórych innych ustaw, http://sejm.gov.pl/Sejm8.nsf/PrzebiegProc.xsp?id=66 171D494347FFC6C125807D00395D70 (dostęp 10 kwietnia 2020 r.). 
rodzicom dzieci z niepełnosprawnościami, okazało się, że budżet państwa nie udźwignie rozszerzenia tych świadczeń także na opiekunów dorosłych osób z niepełnosprawnościami. Do dziś w związku z tym kwestia ta nie została uregulowana w sposób, który satysfakcjonowałby wszystkie grupy opiekunów. Wciąż zatem opiekunowie osób z niepełnosprawnościami otrzymują zróżnicowane wsparcie w zależności od tego, czy niepełnosprawność ich podopiecznego powstała w dzieciństwie czy w wieku dorosłym. Zważywszy na fakt, że opracowanie poświęcone zostało wspieraniu przez państwo opiekunów dorosłych osób z niepełnosprawnościami, zasadne wydaje się w tym miejscu przedstawienie świadczeń opiekuńczych, $\mathrm{z}$ jakich $\mathrm{w}$ aktualnym stanie prawnym ${ }^{28}$ moga skorzystać opiekunowie dorosłych osób z niepełnosprawnościami.

Pierwszym z omawianych świadczeń jest specjalny zasiłek opiekuńczy funkcjonujący w polskim systemie pomocy społecznej od 1 stycznia 2013 r. Przysługuje on osobom, na których zgodnie z przepisami kodeksu rodzinnego i opiekuńczego ciąży obowiązek alimentacyjny ${ }^{29}$, a także małżonkom, jeżeli:

- nie podejmują zatrudnienia lub innej pracy zarobkowej lub

- rezygnują z zatrudnienia lub innej pracy zarobkowej

w celu sprawowania stałej opieki nad osobą legitymującą się orzeczeniem o znacznym stopniu niepełnosprawności albo orzeczeniem o niepełnosprawności łącznie ze wskazaniami: konieczności stałej lub długotrwałej opieki lub pomocy innej osoby w związku ze znacznie ograniczoną możliwością samodzielnej egzystencji oraz konieczności

28 Stan na dzień 1 kwietnia $2020 \mathrm{r}$.

29 W myśl art. 128 i 129 k.r.o. obowiązek dostarczania środków utrzymania, a w miarę potrzeby także środków wychowania, czyli obowiązek alimentacyjny, spoczywa przede wszystkim na krewnych w linii prostej i na rodzeństwie. Obowiązek obciąża bliższych stopniem przed dalszymi. Krewnymi w linii prostej są osoby, z których jedna pochodzi od drugiej. Oznacza to, że synowa czy też zięć nie są krewnymi - nie mogą zatem ubiegać się o specjalny zasiłek opiekuńczy. Podobnie sprawa wygląda w przypadku dzieci rodzeństwa - nie są oni krewnymi w linii prostej, zatem nie mogą otrzymać tego świadczenia. 
stałego współudziału na co dzień opiekuna dziecka w procesie jego leczenia, rehabilitacji i edukacji ${ }^{30}$.

Uzyskanie tego świadczenia warunkowane jest spełnieniem kryterium dochodowego. Przysługuje ono wyłącznie, jeżeli łączny dochód rodziny osoby sprawującej opiekę $e^{31}$ oraz rodziny osoby wymagającej opieki $\mathrm{i}^{32} \mathrm{w}$ przeliczeniu na osobę nie przekracza kwoty kryterium dochodowego wynoszącego 764 zł netto (na podstawie dochodów z roku poprzedzającego okres zasiłkowy z uwzględnieniem utraty i uzyskania dochodu) ${ }^{33}$. Wysokość specjalnego zasiłku opiekuńczego od 1 listopada 2018 r. wynosi $620 \mathrm{zł} \mathrm{miesięcznie.} \mathrm{Organem} \mathrm{właściwym} \mathrm{do} \mathrm{ustalenia}$ i wypłaty tego świadczenia jest wójt, burmistrz lub prezydent miasta właściwy ze względu na miejsce zamieszkania osoby uprawnionej.

Zgodnie $\mathrm{z}$ art. 16a ust. 8 ustawy o świadczeniach rodzinnych specjalny zasiłek opiekuńczy nie przysługuje, jeżeli osoba sprawująca opiekę ma ustalone prawo do emerytury, renty, renty rodzinnej z tytułu śmierci

30 Art. 16a ust. 1 ustawy z 28 listopada 2003 r. o świadczeniach rodzinnych (tekst jedn. Dz. U. z 2020 r., poz. 111).

31 Za dochód osoby sprawującej opiekę, zgodnie z art. 3 pkt 16 ustawy o świadczeniach rodzinnych, uważa się dochód następujących członków rodziny: małżonków, rodziców dzieci, opiekuna faktycznego dziecka oraz pozostających na utrzymaniu dzieci w wieku do ukończenia 25. roku życia, a także dziecka, które ukończyło 25. rok życia i legitymuje się orzeczeniem o znacznym stopniu niepełnosprawności, jeżeli w związku z tą niepełnosprawnością przysługuje świadczenie pielęgnacyjne lub specjalny zasiłek opiekuńczy; do członków rodziny nie zalicza się dziecka pozostającego pod opieką opiekuna prawnego, dziecka pozostającego w związku małżeńskim, a także pełnoletniego dziecka posiadającego własne dziecko.

32 Za dochód rodziny osoby wymagającej opieki, gdy jest ona dorosła, uważa się dochód następujących członków rodziny: a) osoby wymagającej opieki, b) małżonka osoby wymagającej opieki, c) osoby, z którą osoba wymagająca opieki wychowuje wspólne dziecko, d) pozostających na utrzymaniu osób, o których mowa w lit. a-c, dzieci w wieku do ukończenia 25. roku życia - z tym że do członków rodziny nie zalicza się dziecka pozostającego pod opieką opiekuna prawnego, dziecka pozostającego w związku małżeńskim, a także pełnoletniego dziecka posiadającego własne dziecko. Warto zauważyć, że zarejestrowanie w powiatowym urzędzie pracy jako osoba poszukująca pracy lub posiadanie statusu bezrobotnego nie ma wpływu na uprawnienie do specjalnego zasiłku opiekuńczego.

${ }^{33}$ Art. 16a ust. 2 ustawy o świadczeniach rodzinnych. 
małżonka przyznanej w przypadku zbiegu prawa do renty rodzinnej i innego świadczenia emerytalno-rentowego, renty socjalnej, zasiłku stałego, nauczycielskiego świadczenia kompensacyjnego, zasiłku przedemerytalnego, świadczenia przedemerytalnego lub rodzicielskiego świadczenia uzupełniającego, o którym mowa w ustawie o rodzicielskim świadczeniu uzupełniającym ${ }^{34}$, a także gdy osoba ta ma już ustalone prawo do specjalnego zasiłku opiekuńczego, świadczenia pielęgnacyjnego lub zasiłku dla opiekuna, lub legitymuje się orzeczeniem o znacznym stopniu niepełnosprawności. Zasiłek ten nie przysługuje także, gdy osoba wymagająca opieki została umieszczona w rodzinie zastępczej, z wyjątkiem rodziny zastępczej spokrewnionej, w rodzinnym domu dziecka albo, w związku z koniecznością kształcenia, rewalidacji lub rehabilitacji, w placówce zapewniającej całodobową opiekę, w tym w specjalnym ośrodku szkolno-wychowawczym, z wyjątkiem podmiotu wykonującego działalność leczniczą, i korzysta w niej z całodobowej opieki przez więcej niż pięć dni w tygodniu. Świadczenie to jest wykluczone ponadto, gdy:

- na osobę wymagającą opieki inna osoba ma ustalone prawo do wcześniejszej emerytury;

- na osobę wymagającą opieki jest ustalone prawo do dodatku do zasiłku rodzinnego, prawo do specjalnego zasiłku opiekuńczego, prawo do świadczenia pielęgnacyjnego lub prawo do zasiłku dla opiekuna;

- na osobę wymagającą opieki inna osoba jest uprawniona za granicą do świadczenia na pokrycie wydatków związanych z opieką, chyba że przepisy o koordynacji systemów zabezpieczenia społecznego lub dwustronne umowy o zabezpieczeniu społecznym stanowią inaczej.

Należy podkreślić, że specjalny zasiłek opiekuńczy przyznawany opiekunom dorosłych osób z niepełnosprawnościami jest świadczeniem, które nie może być łączone z zasiłkiem dla opiekuna przyznawanym na podstawie ustawy o ustaleniu i wypłacie zasiłków dla opiekunów.

34 Ustawa z 31 stycznia 2019 r. o rodzicielskim świadczeniu uzupełniającym (Dz. U., poz. 303). 
Do kategorii świadczeń opiekuńczych przyznawanych jednak bezpośrednio dorosłej osobie z niepełnosprawnością, a nie jej opiekunowi, należy zaliczyć także zasiłek pielęgnacyjny. Zasiłek ten przyznawany jest w celu częściowego pokrycia wydatków wynikających z konieczności zapewnienia osobie z niepełnosprawnością opieki i pomocy innej osoby w związku z niezdolnością do samodzielnej egzystencji ${ }^{35}$. Warunkiem przyznania tego świadczenia jest legitymowanie się przez dorosłą osobę z niepełnosprawnością orzeczeniem o znacznym stopniu niepełnosprawności lub orzeczeniem o umiarkowanym stopniu niepełnosprawności, jeżeli niepełnosprawność powstała w wieku do ukończenia 21. roku życia ${ }^{36}$. Zasiłek pielęgnacyjny przysługuje w wysokości 215,84 zł miesięcznie. Należy podkreślić, że zasiłek pielęgnacyjny nie przysługuje osobie umieszczonej w instytucji zapewniającej całodobowe utrzymanie, a także osobie uprawnionej do dodatku pielęgnacyjnego ${ }^{37}$. Na podstawie art. 16 ust. 5a ustawy o świadczeniach rodzinnych zasiłek ten nie przysługuje, jeżeli członkom rodziny przysługują za granicą świadczenia na pokrycie wydatków związanych z pielęgnacją tych osób, chyba że przepisy o koordynacji systemów zabezpieczenia społecznego lub dwustronne umowy o zabezpieczeniu społecznym stanowią inaczej.

35 Art. 16 ust. 1 ustawy o świadczeniach rodzinnych.

36 Niezależnie od powyższego, świadczenie to przyznawane jest także niepełnosprawnemu dziecku oraz osobie, która ukończyła 75. rok życia.

37 Jest to świadczenie wypłacane przez Zakład Ubezpieczeń Społecznych osobom, które są uprawnione do świadczeń emerytalno-rentowych i dodatkowo spełniają jeden z poniższych wymogów: - ukończyły 75 lat, - nie ukończyły 75 lat, jednakże zostały uznane za całkowicie niezdolne do pracy oraz samodzielnej egzystencji. Do przyznania dodatku niezbędne jest zatem łączne wystąpienie: całkowitej niezdolności do pracy i niezdolności do samodzielnej egzystencji. Osoba, która ukończyła 75 lat, jest automatycznie uprawniona do otrzymania dodatku, co oznacza, że ma prawo do dodatku pielęgnacyjnego bez potrzeby składania wniosku. Natomiast w przypadku, gdy osoba nie ukończyła 75 lat, a została uznana za całkowicie niezdolną do pracy oraz do samodzielnej egzystencji, dodatek pielęgnacyjny przyznawany jest na wniosek zainteresowanego. Do wniosku niezbędne jest dołączenie orzeczenia lekarza orzecznika ZUS (komisji lekarskiej ZUS), ustalającego całkowitą niezdolność do pracy oraz do samodzielnej egzystencji. 
Postępowanie w sprawie o przyznanie zasiłku pielęgnacyjnego wszczyna się na podstawie wniosku o ustalenie prawa do zasiłku pielęgnacyjnego.

Ostatnim omawianym w tym miejscu świadczeniem jest zasiłek dla opiekuna, który nie jest świadczeniem opiekuńczym, bowiem przyznawany jest na podstawie ustawy o ustaleniu i wypłacie zasiłków dla opiekunów, nie zaś ustawy o świadczeniach rodzinnych. Zasiłek ten nie jest już obecnie przyznawany ${ }^{38}$, jednak zostanie w tym miejscu przedstawiony $z$ uwagi na jego znaczenie dla dalszych wywodów. Warto podkreślić, że jest on formą rekompensaty. Przysługuje on wyłącznie osobom, które opiekują się dorosłymi osobami z niepełnosprawnościami i na skutek nowelizacji ustawy o świadczeniach rodzinnych z dniem 1 lipca 2013 r. utraciły prawo do świadczenia pielęgnacyjnego, a jednocześnie nie spełniły kryterium dochodowego do otrzymania specjalnego zasiłku opiekuńczego, pozostając bez wsparcia państwa.

Zasiłek dla opiekuna $\mathrm{z}$ tytułu rezygnacji $\mathrm{z}$ zatrudnienia lub innej pracy zarobkowej przysługuje osobom, na których zgodnie z przepisami kodeksu rodzinnego i opiekuńczego ciąży obowiązek alimentacyjny, z wyjątkiem osób o znacznym stopniu niepełnosprawności:

- jeżeli nie podejmują lub rezygnują z zatrudnienia lub innej pracy zarobkowej w celu sprawowania opieki nad osobą legitymującą się orzeczeniem o znacznym stopniu niepełnosprawności;

- jeżeli opiekun zaprzestał prowadzenia gospodarstwa rolnego;

- jeżeli małżonkowie rolników lub domownicy zaprzestali prowadzenia przez nich gospodarstwa rolnego albo wykonywania przez nich pracy w gospodarstwie rolnym.

Osobom innym niż spokrewnione w pierwszym stopniu $\mathrm{z}$ osobą wymagającą opieki przysługuje zasiłek dla opiekuna, gdy nie ma osoby spokrewnionej w pierwszym stopniu lub gdy osoba ta nie jest w stanie sprawować opieki.

38 Wniosek musiał być złożony w okresie od 15 maja 2014 r. do 15 września 2014 r. Jeżeli w tym czasie toczyło się postępowanie o wydanie orzeczenia o niepełnosprawności lub orzeczenia o stopniu niepełnosprawności osobie, nad którą jest sprawowana opieka, wniosek mógł być złożony nie później niż w terminie czterech miesięcy od dnia wydania tego orzeczenia. 
Zasiłek ten jest wypłacany niezależnie od dochodu i wynosi $620 \mathrm{zl}$ netto miesięcznie, wraz z ustawowymi odsetkami za czas niepobierania świadczenia. Prawo do zasiłku dla opiekuna ustalane jest na czas nieokreślony, chyba że orzeczenie o niepełnosprawności lub orzeczenie o stopniu niepełnosprawności zostało wydane na czas określony. Uprawnienie do pobierania zasiłku dla opiekuna podlega weryfikacji co pół roku - w tym celu przeprowadzany jest wywiad środowiskowy $z$ rodziną. Wywiad ten jest także przeprowadzany wówczas, gdy istnieją wątpliwości co do faktu sprawowania opieki przez osobę pobierającą zasiłek dla opiekuna.

Zasiłek dla opiekuna nie przysługuje, jeśli osoba sprawująca opiekę:

- ma ustalone prawo do emerytury, renty, renty rodzinnej z tytułu śmierci małżonka przyznanej w przypadku zbiegu prawa do renty rodzinnej i innego świadczenia emerytalno-rentowego, renty socjalnej, zasiłku stałego, nauczycielskiego świadczenia kompensacyjnego, zasiłku przedemerytalnego lub świadczenia przedemerytalnego;

- osobie ubiegającej się o zasiłek dla opiekuna zostało ustalone prawo do specjalnego zasiłku opiekuńczego lub świadczenia pielęgnacyjnego.

Podobnie zasiłek nie zostanie przyznany, jeżeli osoba wymagająca opieki:

- pozostaje w związku małżeńskim, chyba że współmałżonek legitymuje się orzeczeniem o znacznym stopniu niepełnosprawności;

- na osobę wymagającą opieki jest ustalone prawo do wcześniejszej emerytury;

- członek rodziny osoby sprawującej opiekę ma ustalone prawo do dodatku z tytułu opieki nad dzieckiem w okresie korzystania $\mathrm{z}$ urlopu wychowawczego do zasiłku rodzinnego, specjalnego zasiłku opiekuńczego lub świadczenia pielęgnacyjnego;

- na osobę wymagającą opieki jest ustalone prawo do dodatku $\mathrm{z}$ tytułu opieki nad dzieckiem w okresie korzystania $\mathrm{z}$ urlopu wychowawczego do zasiłku rodzinnego, prawo do specjalnego zasiłku opiekuńczego lub prawo do świadczenia pielęgnacyjnego; 
- na osobę wymagającą opieki inna osoba jest uprawniona za granicą do świadczenia na pokrycie wydatków związanych z opieką, chyba że przepisy o koordynacji systemów zabezpieczenia społecznego lub dwustronne umowy o zabezpieczeniu społecznym stanowią inaczej.

\section{Próby ZASTĄPIENIA USTAWODAWCY PRZEZ ORGANY WŁADZY} SĄDOWNICZEJ - WYROKI SĄDÓW UWZGLĘDNIAJĄCE TEZY SFORMUŁOWANE POD ADRESEM USTAWODAWCY PRZEZ Trybunae Konstytucyjny

Do dzisiaj wyrok Trybunału Konstytucyjnego z października 2014 r. pozostaje niewykonany, co oznacza, że rodziny osób z niepełnosprawnościami traktowane są przez państwo skrajnie nierówno. W praktyce może to oznaczać, że dwie rodziny mogą się opiekować dorosłymi dziećmi z niepełnosprawnościami, ale w jednej opiekun dostanie $1830 \mathrm{zł}$ (wysokość świadczenia pielęgnacyjnego w 2020 r.), a w drugiej - 620 zł (wysokość specjalnego zasiłku opiekuńczego w 2020 r.) i to tylko wtedy, gdy w takiej rodzinie dochód na osobę nie przekracza 764 zł. Wysokość pomocy zależy od tego, czy niepełnosprawność była stwierdzona w dzieciństwie (wtedy pomoc jest wyższa), czy w wieku dorosłym (bo jest to skutek np. wypadku komunikacyjnego). Problem ten dostrzegły już sądy administracyjne, które dokonując prokonstytucyjnej wykładni, zaczęły uchylać decyzje administracyjne odmawiające opiekunom dorosłych osób z niepełnosprawnościami świadczenia pielęgnacyjnego ${ }^{39}$. Warto w tym miejscu wskazać przykłady orzeczeń, w których sądy nie

39 Warto zaznaczyć, że jeszcze w 2016 r. można wskazać sytuacje, gdy skargi opiekunów oddalane były z uwagi na fakt niespełnienia niekonstytucyjnego kryterium wskazanego w art. 17 ust. 1 b ustawy o świadczeniach rodzinnych. Takie sytuacje miały miejsce w WSA w Gdańsku w 2016 r., w WSA w Olsztynie w 2015 r. i 2016 r., WSA w Białymstoku w 2016 r., WSA w Warszawie w 2014 r. i 2015 r. Por. opinia przyjaciela sądu przygotowana przez Helsińską Fundację Praw Człowieka w sprawie Tomasz Łuczkiewicz i inni p. Polsce, s. 7, http://www.hfhr.pl/wp-content/uploads/2018/09/\%C5\%8luczkiewicz-p.-Polsce-amicus_PL_FINAL.pdf (dostęp 10 kwietnia 2020 r.). 
ograniczyły się tylko do wykładni językowej, lecz analizując sprawę, odwoływały się także do dyrektyw pozajęzykowych. Nie ulega bowiem wątpliwości, że do weryfikacji spełniania przez organy władzy publicznej obowiązków w zakresie wspierania opiekunów dorosłych osób z niepełnosprawnościami środki wykładni językowej są absolutnie niesatysfakcjonujące ${ }^{40}$.

Z uwagi na zastosowanie pozajęzykowych narzędzi wykładniczych warto przytoczyć wyrok WSA w Bydgoszczy z 24 czerwca 2014 r. ${ }^{41}$, w którym podkreślił on, że zróżnicowanie wprowadzone w art. 17 ust. lb ustawy o świadczeniach rodzinnych godzi w normatywnie określoną zasadę równości (art. 32 ust. 1 Konstytucji). Zdaniem sądu „honorowanie przepisu w dotychczasowym brzmieniu byłoby nie do pogodzenia $z$ funkcją i modelem ochrony praw jednostki realizowanej przez sądy administracyjne, którym przyznaje się kompetencję do bezpośredniego stosowania Konstytucji w przypadku usunięcia z porządku prawnego fragmentu przepisu”. Ponadto WSA zauważył, że: „Instytucja sygnalizacji ma charakter postulatywny, nie zaś normatywny. Jeśli sądy administracyjne, kierując się sugestią Trybunału Konstytucyjnego zawartą w pkt 8 uzasadnienia wyroku, będą stosować przepis art. 17 ust. 1 b ustawy o świadczeniach rodzinnych w dotychczasowym brzmieniu i ustawodawca nie wykona zaleceń Trybunału (listę wielu takich przypadków zawierają coroczne sprawozdania składane Sejmowi przez Prezesa Trybunału Konstytucyjnego), jednostki, których prawa zostały naruszone treścią tego przepisu, zostaną pozbawione ochrony. Natomiast aktywność sądów administracyjnych może mieć decydujący wpływ na działania legislacyjne, dopełniając w ten sposób zobowiązania wskazane dla ustawodawcy w pkt 7 i 8 uzasadnienia wyroku Trybunału Konstytucyjnego". Sąd zwrócił także uwagę na fakt, że TK w wyroku z października 2014 r., derogując przepis art. 17 ust. 1b ustawy o świadczeniach rodzinnych, nie skorzystał z przewidzianej w art. 190 ust. 3 Konstytucji możliwości odroczenia utraty jego mocy

\footnotetext{
40 M. Borski, op. cit., s. 188-190.

41 Wyrok WSA w Bydgoszczy z 24 czerwca 2014 r., II SA/Bd 327/15, «Legalis» nr 1338183.
} 
obowiązującej. Zdaniem WSA w Bydgoszczy „oznacza to, że bezpośrednim skutkiem orzeczenia jest utrata przez ten przepis (we wskazanym w wyroku zakresie) domniemania konstytucyjności. Kwestia ta jest tym bardziej istotna, skoro stwierdzona została niezgodność z Konstytucją danego przepisu, to Sąd nie może tej okoliczności nie brać pod uwagę". Przedstawiona powyżej argumentacja potwierdzona została w wyroku WSA w Łodzi z 29 lipca 2015 r. $^{42}$

Przykładem sięgnięcia przez sąd po narzędzia badawcze wykraczające poza narzędzia językowo-logiczne jest także wyrok WSA w Krakowie ${ }^{43}$, w którym uchylił on decyzje (zarówno Samorządowego Kolegium Odwoławczego, jak i poprzedzającą ją decyzję organu pierwszej instancji) odmawiające prawa do świadczenia pielęgnacyjnego mamie sprawującej opiekę nad niepełnosprawnym od 26. roku życia synem ${ }^{44}$. Podstawą zaskarżenia decyzji był wyrok Trybunału Konstytucyjnego, który w 2014 r. zakwestionował przepisy ustawy o świadczeniach rodzinnych w zakresie, w jakim różnicuje on prawa opiekunów do świadczenia pielęgnacyjnego w zależności od daty powstania niepełnosprawności. Zgodnie z wyrokiem stwierdzenie niekonstytucyjności określonego przepisu ustawy ze swej istoty tworzy nowy stan prawny. Wniosek o przyznanie świadczenia pielęgnacyjnego złożony przez opiekuna dorosłej osoby niepełnosprawnej w takim stanie prawnym organy mają rozpatrzyć z wyłączeniem tej części tego przepisu, która została ostatecznie uznana za niekonstytucyjną. Jak bowiem słusznie zauważył sąd: „Przyjęcie, że stwierdzenie niekonstytucyjności przepisu nie przekłada się na ukształtowanie nowego stanu prawnego, jest sprzeczne z zasadami państwa prawa, które organy mają obowiązek wcielać w życie”. Warto zauważyć,

42 Wyrok WSA w Łodzi z 29 lipca 2015 r., II SA/Łd 424/15, «Legalis» nr 1341378.

43 Wyrok WSA w Krakowie z 26 lipca 2017 r., III SA/Kr 647/17, «Legalis» nr 1650624.

44 W wyniku wypadku doznał on ciężkich wieloodłamowych złamań obu kończyn dolnych. Mimo długiego upływu czasu nie mógł on wrócić do zdrowia na skutek braku zrostu kostnego. Powrót do zdrowia był możliwy wyłącznie dzięki długiej i kosztownej rehabilitacji. Tymczasem sytuacja rodziny uległa pogorszeniu. Mama poświęciła się opiece nad niepełnosprawnym synem, a dochody ojca i zasiłki z pomocy społecznej nie wystarczały na życie, lekarstwa, sprzęt rehabilitacyjno-medyczny i tak bardzo potrzebną rehabilitację. 
że wydane przez WSA orzeczenie spowodowało, że w grudniu 2017 r. ośrodek pomocy społecznej po ponownym rozpatrzeniu sprawy wydał decyzję przyznającą świadczenie pielęgnacyjne z uwzględnieniem stanowiska sądu.

Opisany wyżej wyrok i argumentacja w nim przyjęta stanowią kontynuację linii orzeczniczej zaprezentowanej już wcześniej w orzeczeniach NSA ${ }^{45}$. W wyroku z 14 grudnia 2016 r. ${ }^{46}$ Naczelny Sąd Administracyjny skonstatował, że „podziela w całości pogląd prezentowany w orzecznictwie, zgodnie z którym nie jest dopuszczalne oparcie decyzji odmawiającej przyznania prawa do świadczenia pielęgnacyjnego i rozstrzygnięcia sądu w takiej sprawie na tej części przepisu art. 17 ust. 1b ustawy o świadczeniach rodzinnych, która została uznana za niezgodną z art. 32 ust. 1 Konstytucji RP"47. Z kolei w wyroku z 21 lutego 2018 r. ${ }^{48}$ NSA odniósł się także do relacji między świadczeniem pielęgnacyjnym a zasiłkiem dla opiekuna, stwierdzając, że fakt uzyskania zasiłku dla opiekuna nie może być przesłanką uniemożliwiającą powrót do korzystniejszego świadczenia pielęgnacyjnego ${ }^{49}$. Zdaniem sądu „art. 17 ust. 5 pkt 1 lit. b ustawy o świadczeniach rodzinnych nie może wykluczać prawa do świadczenia pielęgnacyjnego osobie, której

45 Trzeba jednak pamiętać, że początkowo NSA zupełnie inaczej oceniał skutki wyroku TK z 21 października 2014 r. dla opiekunów dorosłych osób z niepełnosprawnościami. W wyroku z 10 lutego 2015 r., I OSK 2916/14, NSA uznał, że wyrok TK nie kreuje żadnych zmian w sytuacji skarżącego opiekuna i aby przyznać opiekunowi dorosłej osoby z niepełnosprawnością świadczenie pielęgnacyjne, niezbędne jest wprowadzenie odpowiednich zmian legislacyjnych. Pogląd taki wyraził również NSA w wyroku z 1 października 2015 r., I OSK 519/14.

46 Wyrok NSA z 14 grudnia 2016 r., I OSK 1614/16, «Legalis» nr 1555081.

47 Pogląd ten wyraźnie prezentowany jest m.in. w następujących wyrokach NSA: z 6 lipca 2016 r., I OSK 223/16, «Legalis» nr 1511372; z 2 sierpnia 2016 r., I OSK 923/16, «Legalis» nr 1511798; z 7 września 2016 r., I OSK 755/16, «Legalis» nr 1512219; z 4 listopada 2016 r., I OSK 1578/16, «Legalis» nr 1554336, i z 10 listopada 2016 r., I OSK 1512/16, «Legalis» nr 1554578.

48 Wyrok NSA z 21 lutego 2018 r., I OSK 2758/17, «Legalis» nr 1717865.

49 Podobne wypowiedzi można odnaleźć w: wyroku WSA w Olsztynie z 13 czerwca 2017 r., II SA/Ol 392/17, «Legalis» nr: 1624994; wyroku WSA w Białymstoku z 9 maja 2017 r., II SA/Bk 189/17, «Legalis» nr 1599232; wyroku WSA w Białymstoku z 28 marca 2017 r., II SA/Bk 139/17, «Legalis» nr 1580777. 
to prawo odebrano regulacją niekonstytucyjną, przymuszając niejako do ubiegania się o świadczenie mniej korzystne (zasiłek dla opiekuna), którego uzyskanie jest z kolei przesłanką uniemożliwiającą powrót do uzyskiwania świadczenia poprzedniego (świadczenia pielęgnacyjnego)".

\section{ZAKOŃCZENIE}

Zapewnienie efektywnego systemu wsparcia organów władzy publicznej dla dorosłych osób z niepełnosprawnościami i ich opiekunów powinno być podstawowym zadaniem państwa. Dotychczasowe rozważania nie nastrajają niestety optymistycznie. Wydaje się, że brak w tym zakresie przemyślanych rozwiązań systemowych, zaś wprowadzone instrumenty wsparcia cechuje przypadkowość i incydentalność. Polski ustawodawca zaczyna reagować zwykle bardzo nerwowo dopiero wtedy, gdy pojawia się zagrożenie w postaci protestów społecznych. Większość parlamentarna dopiero wtedy zaczyna reagować naprędce, przygotowując rozwiązania, które mają owe protesty wyciszyć. Takie pospieszne działania obarczone są niestety ogromnym ryzykiem błędów legislacyjnych, nie mówiąc już nawet o tworzeniu konsekwentnego i systemowego wsparcia. Tymczasem stworzenie systemu wsparcia dla dorosłych osób z niepełnosprawnościami i ich opiekunów wymaga namysłu i kompleksowego przeglądu istniejących rozwiązań. Co szczególnie istotne, w tworzeniu tego systemu muszą uczestniczyć sami zainteresowani. Bardzo często przeciwko przyjęciu określonych rozwiązań podnoszone są argumenty ekonomiczne. Mówi się o wysokich kosztach wprowadzenia danego rozwiązania. Rzeczywiście, jeśli na dany problem spojrzy się z perspektywy jednego konkretnego świadczenia, to koszty mogą wydawać się wysokie, jeśli jednak dokonać refleksji nad całym systemem wsparcia, to wydaje się, że nie podnosząc znacząco wydatków, można byłoby zapewnić wsparcie systemowe na zdecydowanie wyższym poziomie niż do tej pory. Poza tym trzeba pamiętać, że opiekunom osób z niepełnosprawnościami powinno być zagwarantowane wsparcie finansowe, które pozwoli uniknąć ubóstwa rodzinom, w których żyją osoby z niepełnosprawnościami. Zapewnienie pomocy materialnej 
na odpowiednim poziomie stanowi bowiem gwarancję poszanowania godności i autonomii osób z niepełnosprawnościami. Nie ulega wątpliwości, że warunki ubiegania się o świadczenia ze środków publicznych nie mogą być skonstruowane w sposób naruszający zasadę równego traktowania, a z taką sytuacją mamy do czynienia obecnie.

Niekonsekwentne działania i ewidentne zaniechania ustawodawcy są w pewnym stopniu niwelowane przez władzę sądowniczą, która stara się, na ile to możliwe, „zastąpić” ustawodawcę. Jak była już wcześniej mowa, bardzo dobrze widać to na przykładzie świadczeń opiekuńczych wypłacanych opiekunom dorosłych osób z niepełnosprawnościami. Co szczególnie istotne, aktywność władzy sądowniczej zaczyna przynosić pierwsze wymierne efekty. Konsekwentna linia orzecznicza sądów administracyjnych zaprezentowana w tym opracowaniu została dostrzeżona także przez organy administracji publicznej wyższego stopnia, jakimi są samorządowe kolegia odwoławcze (SKO). Stowarzyszenie na rzecz Niepełnosprawnych SPES prowadzące program pomocy prawnej dla osób, które ze względu na niepełnosprawność, wiek lub z innych powodów są niezdolne do samodzielnego prowadzenia swych spraw wymagających pomocy prawnej, wskazuje przykład SKO, dwukrotnie uchylającego decyzje, w których córce pobierającej zasiłek dla opiekuna odmówiono prawa do świadczenia pielęgnacyjnego. Powodem odmowy było zastosowanie niekonstytucyjnego przepisu ustawy o świadczeniach rodzinnych warunkującego to prawo datą powstania niepełnosprawności osoby wymagającej opieki. Kolegium po rozpatrzeniu odwołań przyznało świadczenie pielęgnacyjne z racji opieki nad mamą, której niepełnosprawność powstała po ukończeniu 25. roku życia ${ }^{50}$.

Niestety, wciąż jeszcze takie działania organów administracji publicznej stanowią rzadkość, zaś na porządku dziennym jest bezduszne stosowanie niekonstytucyjnych rozwiązań pod pretekstem braku środków. Bardzo dobrze obrazuje to przykład sopockiego Miejskiego Ośrodka Pomocy Społecznej, który wypłacał świadczenia pielęgnacyjne opiekunom dorosłych osób z niepełnosprawnościami od daty wejścia w życie

50 Por. https://spes.org.pl/co-robimy/program-pomocy-prawnej/zmiana-zasilku-dla-opiekuna-na-swiadczenie-pielegnacyjne-2018 (dostęp 10 kwietnia 2020 r.). 
wyroku Trybunału Konstytucyjnego, zgodnie z sentencją wyroku, nie oglądając się na niekonstytucyjne przepisy ustawy o świadczeniach rodzinnych. W reakcji na te działania Wojewoda Pomorski przeprowadził na zlecenie Ministra Rodziny, Pracy i Polityki Społecznej kontrolę w zakresie ustalania prawa do świadczeń pielęgnacyjnych. Wykrywszy, że opiekunowie dorosłych osób z niepełnosprawnościami dostają tam takie samo wsparcie, jak opiekunowie dzieci, nakazał zwrot 846 310,26 zł wraz z odsetkami. Powołał się przy tym na stanowisko Ministra Rodziny, Pracy i Polityki Społecznej z 9 kwietnia 2018 r. ${ }^{51}$, że przy przyznawaniu prawa do świadczeń pielęgnacyjnych opiekunom dorosłych osób niepełnosprawnych organy właściwe mają bezwzględny obowiązek przestrzegania przepisów niekonstytucyjnej ustawy (art. 17 ust. 1b ustawy o świadczeniach rodzinnych), a nie wyroku TK. Ministerstwo Rodziny, Pracy i Polityki Społecznej podkreśla niemal jak mantrę, że wyrok TK nie kreuje roszczenia do otrzymania świadczenia pielęgnacyjnego po stronie opiekunów osób z niepełnosprawnościami, których niepełnosprawność powstała po 18. lub po 25. roku życia w przypadku kontynuowania nauki.

ŚWIADCZENIA OPIEKUŃCZE DLA OPIEKUNÓW DOROSŁYCH OSÓB Z NIEPEŁNOSPRAWNOŚCIAMI - PRZYKŁAD NIEKONSEKWENTNEJ POLITYKI PAŃSTWA

\section{Streszczenie}

Zapewnienie efektywnego systemu wsparcia organów władzy publicznej dla dorosłych osób z niepełnosprawnościami i ich opiekunów powinno być podstawowym zadaniem państwa. Tymczasem analiza istniejących regulacji prawnych prowadzi do wniosku, że brak w tym zakresie przemyślanych rozwiązań systemowych, zaś wprowadzone instrumenty wsparcia cechuje przypadkowość i incydentalność. Celem autora było uzasadnienie sformułowanej tezy o niekonsekwentnej

51 Por. pismo Ministra Rodziny, Pracy i Polityki Społecznej z 9 kwietnia 2018 r., znak DSR-IV.074.12.2018.GJ. 
polityce państwa w zakresie świadczeń opiekuńczych przyznawanych opiekunom dorosłych osób z niepełnosprawnościami. W tym celu wskazuje on, że rodziny osób $\mathrm{z}$ niepełnosprawnościami traktowane są przez państwo skrajnie nierówno. Wysokość pomocy zależy od tego, czy niepełnosprawność była stwierdzona w dzieciństwie (wtedy pomoc jest wyższa), czy w wieku dorosłym (bo jest to skutek np. wypadku komunikacyjnego). Niekonsekwencję tę autor ukazuje, zderzając istniejące regulacje normatywne z orzecznictwem sądów administracyjnych. Całość zaś osadza w kontekście dwóch przełomowych orzeczeń Trybunału Konstytucyjnego, które do dziś nie zostały przez ustawodawcę wykonane.

\section{Care Benefits for Carers of Disabled Adults: an Example of InCOnsistency in the Polish Policy}

\section{Summary}

The provision of effective support for public authorities responsible for the welfare of disabled adults and their carers should be one of the fundamental tasks of the state. However, a review of the legal provisions currently in force in Poland leads to a conclusion that there are no wellplanned, systemic regulations, and the measures in force are arbitrary and disordered. The aim of this study is to show that Polish policy on benefits granted to the carers of disabled adults is inconsistent. The way the families of disabled adults are treated is extremely erratic and unfair. The amount of the subsidy carers receive depends on whether the disability was diagnosed and officially recorded when the disabled person was still a child, in which case the benefit is higher, or whether the disability was not confirmed until the disabled person had reached adulthood, e.g. as a result of a road accident. The inconsistency of the provisions is presented in the light of the current judicial practice of Polish administrative courts. The issue is described in the context of two landmark rulings handed down by the Polish Constitutional Tribunal, which the legislator has still not implemented. 
Słowa kluczowe: opiekun; dorosła osoba z niepełnosprawnością; Trybunał Konstytucyjny; świadczenie pielęgnacyjne; świadczenia opiekuńcze; specjalny zasiłek opiekuńczy; sądownictwo administracyjne.

Keywords: carer; disabled adult; the Polish Constitutional Tribunal; benefit; allowance; special care allowance; the Polish administrative courts.

\section{Bibliografia}

Bakalarczy K R., Polityka wsparcia rodzin z osobami niepetnosprawnymi. $W$ cieniu wyroków Trybunału Konstytucyjnego RP i protestów społecznych, «Studia z Polityki Publicznej» 1/2015, s. 63-80.

BAKALARCZYK R., Wybrane problemy zabezpieczenia społecznego osób opiekujących się niesamodzielnymi bliskimi - wyzwania dla Sejmu VIII kadencji, «Ubezpieczenia Społeczne. Teoria i Praktyka» 3/2016, s. 43-66.

Borski M., Publiczne formy wspierania opiekunów osób z niepełnosprawnościami, Sosnowiec 2018.

Ciszkowska-Giedziun M., Instytucjonalne formy wsparcia osób starszych w Anglii, [w:] Działanie społeczne w pracy socjalnej na progu XXI wieku, red. E. Kartowicz, A. Olubiński, Toruń 2003, s. 497-504.

Drozdowska U., Status prawny partnera pacjenta $w$ świetle uregulowań polskiego prawa medycznego, «Miscellanea Historico-Iuridica»13.2/2014, s. $265-280$.

DudziŃska A., Wymagana informacja udzielana pacjentowi, «PiP»63.8/2008, s. $90-102$.

Dukiet-NagóRska T., Świadoma zgoda pacjenta w ustawodawstwie polskim, «Prawo i Medycyna» 6-7/2000, s. 78-95.

Hooyman M.R., Kiyak H.A., Social gerontology. A multidisciplinary perspective, Pearson Education, Inc., Boston 2011.

Konieczniak P., Status prawny opiekuna faktycznego w prawie medycznym, «Prawo i Medycyna» 2/2014, s. 69-90.

RosochackA-GMitrzaK M., Wsparcie opiekunów nieformalnych - w stronę równowagi społecznych oczekiwań i opiekuńczych możliwości rodzin, [w:] Publiczna troska, prywatna opieka. Społeczności lokalne wobec osób starszych, red. M. RaCŁAW, Warszawa 2011, s. 137-154.

Świderska M., Zgoda pacjenta na zabieg medyczny, Toruń 2007. 